\title{
APEC INVESTMENT, TRADE LIBERALISATION AND CHINA'S ECONOMIC ADJUSTMENT
}

\section{SUN XUEGONG}

The 15th National Congress of the Chinese Communist Party (CPC), concluded in September 1996, reaffirmed that China would continue its reform and opendoor policy. Investment and trade liberalisation are important parts of the strategy to bring a prosperous and stable China into the new millennium. At the APEC Osaka summit, China pledged to take an active part in the APEC liberalisation process. Since then, China has unilaterally taken major steps to cut tariff rates and dismantle non-tariff barriers, bringing China's average tariff rate from 36 per cent-almost the highest in the world - to 15 per cent- the target set for 2000-and abolishing import control measures such as quotas, licensing and other direct administrative controls on more than 170 frequently traded commodities. Further liberalisation is also on the agenda. China's commitment to liberalisation is strong and it has made substantial progress in implementation.

\section{ECONOMICSTRUCTURALADJUSTMENT: REAPINGTHE BENEFITS OF LIBERALISATION}

There is unanimous agreement (World Bank 1997; Zhang et al. 1997) that trade liberalisation will bring enormous welfare benefits to China's economy. In particular, it will dramatically expand the labour-intensive sectors of the economy without causing output in other sectors to decline, if China's offers of tariff reductions and the phasing out of non-tariff barriers are implemented. This will help China maintain its momentum of economic growth in the long run and promote its industrialisation drive. However, to realise the expected potential benefits and to cope with the challenges that will accompany liberalisation, adjustment of China's economic structure is essential. The experience of other countries shows that without a sound economic structure, liberalisation does 
not necessarily bring benefits. China's present inefficient economic structure will likely decrease its chances of realising the benefits, and magnify the risks, of liberalisation. As a transitional country with a long experience of a closed market and a planned economic system, and as the largest developing economy in the world undergoing rapid industrialisation, China's need for economic structural adjustment is much more fundamental and comprehensive than that of other countries undergoing a similar transition process.

While there are many facets of China's economic structural adjustment in response to proposed trade liberalisation, this chapter seeks only to identify and deal with a few key fields that are crucial to preparing China adequately for liberalisation. Considering that China is still in the throes of transition from a planned to a market economy, the first key field is reform of the economic system, an aspect of fundamental importance in the context of liberalisation. The notion that a country will necessarily benefit from free trade is predicated on the assumption that the market mechanism in that country functions well. If not, the story is totally different. After 20 years of concerted efforts, China has basically established a market system but there is still much work to do. Last year, the party congress called for strategic readjustment of the state-owned economy. This was a signal that China's policy of incremental reform-which had proved very effective in the past two decades, and was characterised by allowing the non-state sector to develop freely while avoiding dramatic reform in the troublesome state sector-had come to an end. Further reform will focus on state-owned enterprises (SOEs), and bolder reform measures will be introduced. Although not intended to deal with the issues raised by free trade, SOE reform is relevant to the process of trade liberalisation. SOEs are the parts of the Chinese economy most vulnerable to external shocks. However, SOEs have strong bargaining power to influence government policymaking. If the SOE reform program cannot be implemented smoothly, the adjustment costs of liberalisation will be very high and this, in turn, will damage the process of trade liberalisation.

The market structure of China's industries is another matter of concern for trade liberalisation. It is an undeniable fact that all countries want to profit from participation in international competition. But nowadays, the possession of comparative advantage does not necessarily guarantee that a country will be competitive in a world market dominated by huge multinational corporations. China's unique experience of decentralised incremental reform has left its industrial organisational structure ill-prepared for fierce international competition. The overall size of China's economy is approaching that of a developed country, but individual Chinese enterprises are far smaller than their counterparts in developed countries. The relatively small size of its enterprises has weakened China's competitiveness in many ways, particularly in terms of capability in 
worldwide marketing and R\&D. China is now encouraging its enterprises to establish conglomerates through mergers or other means of capital reorganisation. Adjustment of its market structure will help China gain the confidence to integrate more aggressively with the global economy and set the country firmly on the path of trade liberalisation.

As the most populous country in the world with a long history of struggles against starvation, the importance of the grain sector in China cannot be overemphasised. Adjustment in the grain sector is one of the most sensitive and controversial issues both in China and abroad. In response to changing comparative advantage, adjustment in this sector is already underway. However, given China's large territory and the wide disparities among regions, we argue that this adjustment will be initiated by reallocating domestic resources and reforming the institutional framework to tap the remaining potential of China's grain production. Inevitably, China will integrate with the world grain market. But it will take time, and the speed of this process will not only be affected by economic factors but also by political ones, given the strategic nature of food production.

China's process of trade liberalisation is undoubtedly conditioned by adjustments in these key fields. Coordination of the trade liberalisation process with domestic structural adjustment is essential if China is to achieve its goal at least possible cost and minimal instability.

\section{ECONOMIC STRUCTURALADJUSTMENT IN KEY FIELDS AND ITS IMPLICATIONS FOR TRADE LIBERALISATION}

\section{STATE-OWNED ENTERPRISE REFORM}

One of the main benefits of trade liberalisation is that it intensifies domestic competition, providing incentives for domestic enterprises to improve performance and efficiency, the real engines of economic development. However, this only occurs when domestic enterprises are sensitive to market changes.

Within the Chinese economy, there is a distinct dichotomy between the stateowned sector and the non-state-owned sector. The market-oriented non-state sector-a byproduct of incremental reform--is heavily concentrated in labourintensive industries in which China's comparative advantage is believed to reside. Trade liberalisation will boost the development of the non-state sector through increased flexibility and accessibility to bigger markets and previously unavailable resources. The state sector, however, presents a different picture. While the state sector has undergone dramatic change, the transformation falls far short of government objectives. State-owned enterprises- to which the majority of China's economic resources are allocated - cannot be considered as enterprises in the true sense of the word until the establishment of a modern enterprise 
system is complete. State-owned enterprises continue to lack the incentives and vitality necessary to participate in market competition. This defect in the market mechanism will diminish the real benefits of trade liberalisation.

Inefficiency and relative concentration in capital-intensive industries, combined with weak international competitiveness, make the state sector the part of China's economy most vulnerable under trade liberalisation. In recent years, there has been increasing evidence of the linkages between the poor performance of SOEs and external competition, especially in the capital goods industries, such as machine building and electrical equipment. At the introduction of the open-door policy, domestically-produced capital goods accounted for over 90 per cent of total supply, but by the mid-1990s, their market share fallen to less than 40 per cent. Basic mechanical equipment such as machine tools lost more than 70 per cent of their market share (Hu 1996). This has raised major concerns about the role of trade liberalisation and provoked heated debate on policy options. Some people argue that China's long-term dynamic advantage lies in capital-intensive sectors. They are pessimistic about the further expansion of China's labour-intensive sector in the light of deteriorating terms of trade and trade barriers in destination countries. Accordingly, they advocate slowing the process of trade liberalisation to protect these emerging industries. This opposition to liberalisation-especially from the industry sector-is so strong that it cannot easily be ignored by policymakers.

Another concern centres on employment. Ongoing SOE reform and downsizing campaigns in the state-owned sector have already caused more than 10 million workers to be laid off, bringing the real unemployment rate to a record high since reform. Despite government assurances that every laid-off worker will be re-employed, more than half remain unemployed, and the situation is even worse in some interior provinces where SOEs are concentrated. This is regarded as a potential threat to social stability, an issue of real concern to policymakers in China. A rush to liberalise will inevitably exacerbate the unemployment situation. Zhang et al. (1997) estimate employment losses due to trade liberalisation in certain sectors dominated by SOEs. Their findings illustrate that more than 20 per cent of workers will lose their jobs in an average industry, and the industry most strongly affected-the automobile industry-will lose 67 per cent of its jobs (Table 7.1).

Furthermore, the production factors - both capital and labour - in the state sector are stickier than those in the non-state sector. The inertia in the state sector makes it difficult to channel redundant resources into more productive industry. This will create very high adjustment costs as the trade liberalisation process outpaces SOE reform.

It is clear that SOE reform has lagged behind trade liberalisation and has increasingly become an impediment to further liberalisation. Synchronising SOE 
Table 7.1 The effect of trade liberalisation on employment in selected industries

\begin{tabular}{lccc}
\hline Industry & $\begin{array}{c}\text { Employment before } \\
\text { liberalisation } \\
(10,000)\end{array}$ & $\begin{array}{c}\text { Change in } \\
\text { employment } \\
(10,000)\end{array}$ & $\begin{array}{c}\text { Rate of change } \\
(\%)\end{array}$ \\
\hline Colour TVs & 17.58 & -1.68 & -9.54 \\
VCRs & 3.27 & -0.95 & -29.06 \\
Motorcycles & 14.41 & -5.13 & -35.57 \\
Air conditioners & 5.62 & -3.36 & -59.35 \\
Steel & 66.66 & -17.40 & -26.11 \\
Bronze & 16.17 & -1.07 & -6.63 \\
Aluminium & 20.71 & -8.29 & -40.01 \\
Gasoline & 26.55 & -5.98 & -22.53 \\
Diesel oil & 59.78 & -13.14 & -21.98 \\
Synthetic fibres & 19.56 & -2.93 & -14.98 \\
Synthetic rubbers & 14.12 & -3.85 & -27.30 \\
Plastics & 78.70 & -32.16 & -60.86 \\
Automobiles & 10.94 & -7.42 & -67.85 \\
Personal computers & 8.13 & -1.03 & -12.66 \\
Color kinescopes & 12.40 & -2.48 & -20.01 \\
Switchboards & 13.33 & -3.84 & -28.84 \\
\end{tabular}

Source: Zhang, S., Zhang, Y. and Wan, Z., 1997. 'Measuring the cost of China's trade protection', Economic Research, 2:12-22.

reform and trade liberalisation will lead to smoother and less costly adjustment. Speeding up SOE reform rather than slowing the scheduled pace of liberalisation appears to be an efficient and logical solution. The government has pledged that in the coming three years, large and medium-size state-owned enterprises will resolve their current difficulties. China's target for trade liberalisation over the same period is to lower the tariff rate to the average level of developing countries, a new milestone in the drive towards trade liberalisation.

\section{MARKET STRUCTURE}

Unlike traditional trade theory — which is based on assumptions of perfect market competition and constant returns to scale-the assumptions of new trade theory are more realistic. Under this theoretical framework, market structure is an important factor in determining whether a country can benefit from free trade. When the domestic market structure corresponds to the international market structure, free trade is the optimal option, just as traditional trade theory predicts. But when the domestic market is in a state of perfect competition, and the international market is characterised by imperfect competition-such as the 
presence of monopoly or oligopoly - a country will suffer under free trade because of the existence of monopoly rents as well as the unfair advantage multinationals have over domestic producers.

Unfortunately, China is faced with this unfavourable case. Sheng (1996) compares the market structure of China's manufacturing sector with its international counterparts. He finds that the majority of China's manufacturing industries fall into the category of perfect competition, while their foreign counterparts are in a state of imperfect competition (Table 7.2). There is no single industry in China in which the production concentration exceeds 50 per cent, even those industries where scale economies are notable - such as transport equipment and steel.

Another obvious fact is that there is no Chinese enterprise listed among the Fortune 500 biggest companies, although China ranks first in the output of many industrial products around the world. This is partly due to China's unique experience of decentralised reform. This reform has empowered local governments and SOEs to make their own decisions about investment, although they are not true market players. Many of their investment decisions have proven to be short-sighted and irresponsible, resulting in long-standing problems of duplication and uncoordinated regional industrial structures, usually the result of hasty decision-making. China's industrial organisational structure can be described as large, scattered in distribution and disorderly in conduct.

This fact raises the concern that liberalisation will damage domestic enterprises, even if they have comparative advantage or the potential to be productive, due to a biased market structure. Taking the steel industry as an example, China's steel output is ranked the first in the world, but individual firm size is small in relation to foreign competition. The sales volume of Baoshan Steel Corporationthe largest steel company in China-is less than one-tenth that of steel plants in Japan and Korea. Other industries-such as domestic electronics and building materials - are in a similar position. Under these circumstances, multinationals will easily drive domestic enterprises to the wall with the aid of their monopoly power. This will frustrate China's ambition to compete in the world market and may even cause China to pull back from its commitments on trade liberalisation. This partly explains China's reluctance to open some sectors in which it appears to have a comparative advantage.

China is attempting to change its current industrial organisation structure so that it can adapt to international competition. Many people believe that there is still great potential for China to exploit increasing returns to scale in the domestic market, as distinct from the path taken by China's export-led Southeast Asian neighbours. Some policy incentives have been set up to encourage the establishment of conglomerates, although there is some scepticism as to the effectiveness of such artificial incentives. The recent financial crisis in Korea- 
APEC INVESTMENT, TRADE LIBERALISATION AND CHINA'S ECONOMIC ADJUSTMENT

Table 7.2 Market structure of manufactures and expected trade policy Industry

\begin{tabular}{|c|c|c|c|c|c|c|}
\hline ISIC & Industry & $\begin{array}{l}C 4^{a} \\
(\%)\end{array}$ & $\begin{array}{l}\text { Scale of } \\
\text { economy }\end{array}$ & $\begin{array}{l}\text { Domestic } \\
\text { structure }\end{array}$ & $\begin{array}{l}\text { Foreign } \\
\text { structure }\end{array}$ & $\begin{array}{l}\text { Expected } \\
\text { trade policy }\end{array}$ \\
\hline $311-312$ & Food & 9.5 & 0.97 & Perfect & Imperfect & $\begin{array}{l}\text { Rent } \\
\text { transfer/tariff }\end{array}$ \\
\hline 313 & Beverages & 7.6 & 1.29 & Perfect & Imperfect & $\begin{array}{l}\text { Rent } \\
\text { transfer/tariff }\end{array}$ \\
\hline 314 & Tobacco & 31 & 2.33 & Imperfect & Imperfect & Free trade \\
\hline 321 & Textiles & .. & 0.77 & Perfect & Imperfect & $\begin{array}{l}\text { Rent } \\
\text { transfer/tariff }\end{array}$ \\
\hline $322-324$ & $\begin{array}{l}\text { Apparel, } \\
\text { footwear }\end{array}$ & .. & 1.07 & Perfect & Imperfect & $\begin{array}{l}\text { Rent } \\
\text { transfer/tariff }\end{array}$ \\
\hline 323 & Leather & $\therefore$ & 1.04 & Perfect & Perfect & Free trade \\
\hline $331-332$ & $\begin{array}{l}\text { Wood \& } \\
\text { furniture }\end{array}$ &. & 0.29 & Perfect & Perfect & Free trade \\
\hline $341-342$ & $\begin{array}{l}\text { Paper \& } \\
\text { printing }\end{array}$ &.. & 0.77 & Perfect & Imperfect & $\begin{array}{l}\text { Rent } \\
\text { transfer/tariff }\end{array}$ \\
\hline 353-354 & $\begin{array}{l}\text { Oil refining } \\
\text { \& coking }\end{array}$ & 30 & 0.91 & Imperfect & $\begin{array}{l}\text { Market } \\
\text { split }\end{array}$ & $\begin{array}{l}\text { Rent } \\
\text { transfer/tariff }\end{array}$ \\
\hline 351 & Chemical & 8.5 & 1.02 & Perfect & Imperfect & $\begin{array}{l}\text { Rent } \\
\text { transfer/tariff }\end{array}$ \\
\hline 3522 & Pharmacy & 11.0 & 1.23 & Imperfect & Imperfect & Free trade \\
\hline 352 & $\begin{array}{l}\text { Chemical } \\
\text { fibres }\end{array}$ & 32.4 & 1.44 & Imperfect & Imperfect & Free trade \\
\hline 355 & Rubber & 10.9 & 0.52 & Perfect & Market split & $\begin{array}{l}\text { Rent } \\
\text { transfer/tariff }\end{array}$ \\
\hline 356 & Plastic & .. & 0.89 & Imperfect & Imperfect & $\begin{array}{l}\text { Rent } \\
\text { transfer/tariff }\end{array}$ \\
\hline 36 & $\begin{array}{l}\text { Building } \\
\text { materials }\end{array}$ & 2.2 & 0.91 & Perfect & Imperfect & $\begin{array}{l}\text { Rent } \\
\text { transfer/tariff }\end{array}$ \\
\hline 371 & Steel & 23.6 & 0.55 & Imperfect & Market split & $\begin{array}{l}\text { Rent } \\
\text { transfer/tariff }\end{array}$ \\
\hline 372 & $\begin{array}{l}\text { Non-ferrous } \\
\text { metals }\end{array}$ & 12.9 & 1.35 & Imperfect & Imperfect & $\begin{array}{l}\text { Rent } \\
\text { transfer/tariff }\end{array}$ \\
\hline 381 & Metal product & s 3.2 & 1.09 & Perfect & Imperfect & $\begin{array}{l}\text { Rent } \\
\text { transfer/tariff }\end{array}$ \\
\hline 382 & Machinery & 3.8 & 0.40 & Perfect & Imperfect & $\begin{array}{l}\text { Rent } \\
\text { transfer/tariff }\end{array}$ \\
\hline 384 & $\begin{array}{l}\text { Transport } \\
\text { equipment }\end{array}$ & 28.3 & 1.16 & Imperfect & Imperfect & Free trade \\
\hline \multirow[t]{2}{*}{383} & Electrical & 9.8 & 1.06 & Imperfect & Imperfect & Free trade \\
\hline & $\begin{array}{l}\text { Electronic \& } \\
\text { telecomms }\end{array}$ & 11.3 & 0.95 & Imperfect & Imperfect & Free trade \\
\hline 385 & $\begin{array}{l}\text { Instruments } \\
\text { \& meters }\end{array}$ & 17.4 & 1.48 & Imperfect & Imperfect & Free trade \\
\hline
\end{tabular}

Note: ${ }^{a} \mathrm{C} 4$ denotes the percentage of the largest four companies in the total output of their industry; the scale of economy is measured by the sum of $a$ and $b$, coefficients of the Cobb-Douglas production function.

Source: Sheng, L., 1996. 'Market structure of China's manufactures and its implications for trade policy', Economic Research, 8:62-70. 
where the economic structure is dominated by large conglomerates backed by government - has added weight to these concerns and may lead to policy adjustments. However, there have already been several cases of mergers of big companies. In Nanjing, four chemical companies originally belonging to different central and local government departments merged into a giant corporation, forming the largest enterprise in China's chemical industry. In Shanghai, China's largest business, Baoshan Steel Corporation, also purchased a smaller firm, Shanghai Steel Corporation. Many people believe that adjustment in industrial organisational structure is necessary to reconcile the large gap between the size of Chinese firms and their foreign competitors, although how this is to be achieved requires further discussion. Most importantly, the emergence of conglomerates will build up China's confidence to participate aggressively in international competition, and hasten China's integration into the global economy.

To complement these changes in structural policy, China needs to improve its legal system and strengthen the enforcement of competition policy. Even more important is the need to enhance legal awareness within Chinese enterprises. Until recently, no anti-trust or anti-dumping investigations had been launched by Chinese enterprises. At the end of 1996, MOFTEC received its first complaint. Seven Chinese paper-making companies are to sue Canadian competitors for dumping their product on the Chinese market. Using these laws, China's domestic enterprises may find alternative ways to protect their interests rather than closing the door to the outside world in the face of unfair competition from powerful multinationals.

\section{GRAIN SECTORADJUSTMENT}

Of the major developing countries, China is the most poorly endowed with land. The area of arable land per capita in China is only about one-fifth of the world average. Sooner or later, China will lose its comparative advantage in this field, and adjustment is inevitable. In fact, some adjustment in response to changing comparative advantage has already taken place. Since reform, grain production has gradually shifted from the southern coastal region to the northern interior provinces, despite the former region's more favourable natural conditions for grain production. This is a result of the rapid industrialisation of the coastal region in past decades. As industrialisation spreads through the country, China will eventually liberalise its grain sector and integrate into the world grain market. The percentage of imported grain in total grain consumption will increase steadily. Nevertheless, it is still too early to predict by how much the proportion of imported grain will rise, due to the wide variation in projections made by various sources-from almost 50 per cent to only 3 per cent. Adjustment in the grain 
sector from an inward to an outward looking approach will take time. There are several reasons for the uncertainty and slow progress.

First, there is still room for China to undertake internal adjustment in the grain sector, both physically and institutionally. Exploitation of unused land, introduction of high-yield varieties, increasing and balanced use of fertilisers, and improvements to the agricultural infrastructure-especially in water conservation and irrigation systems - are often cited as steps that China should take to tap its potential in grain production. Adjustments like these will allow China's grain production to grow rather than contract. In contrast to the predictions of Lester R. Brown, the dramatic decline in grain production that occurred in the newly industrialising countries will not occur in China. Improvements in the domestic trade infrastructure and grain distribution system will make the country more integrated as a common market and help China take advantage of its large territory and the disparities among regions so that they can develop their own specialisations. This will create more regional trade and even replace some of the international trade that occurs now. Maize exports from the northeast of China may be replaced by imports by Guangdong, for example, something not yet possible due to the poor internal transportation system. Reform of the existing grain trade regime can be seen as another stimulus to grain production. In 1997, a bold measure was taken to reform the state grain trade regime with the aim of streamlining and increasing efficiency. Many people claim that the current regime is merely seeking rent from its control over the grain trade and that this has lowered grain production without protecting the interests of farmers or consumers. Reform of the international grain trade regime is also underway. In the past decade, efforts to regulate shortages or surpluses of grain supply have not proved effective. A net import year often coincides with a good harvest year while a net export year usually occurs in a bad harvest year. This unreasonable trade behaviour has exacerbated fluctuations in grain prices on the domestic market, especially in 1993 when grain price hikes triggered a new round of severe inflation and slowed China's growth rate. More reasonable and stable trade behaviour can be expected under the new regime.

Second, the speed of liberalisation of China's grain sector will be heavily dependent on the openness of China's trade partners to China's labour-intensive production. China's withdrawal from the agricultural sector is only possible if labour-intensive industries accommodate the thousand million farmers moving out of the agricultural sector. China's labour-intensive industries face a serious problem of redundant production capacity. Data from the third national industrial census show that over one-third of industries utilise only half of their production capacity or less. Those industries need the international market to make full use of their production capacity and draw farmers out of the traditional sector. But 
unfortunately, some trading partners limit the access of Chinese products to their markets through quota controls or under the pretext of anti-dumping. Under these circumstances, no one can expect China to open its grain market quickly.

Finally, political concerns also play a role. China's demand for food security and its desire to reduce risk to a manageable level are justifiable. China needs to deal with external concerns that it will exhaust the world's tradable grain supplies or at least increase grain prices on the international market. Some developing countries-whose grain supplies depend heavily on the international market, and are likely to suffer greatly under this scenario-have openly expressed such concerns. All this should prompt China to be prudent in liberalising its grain sector. It is to be expected that the extent of China's involvement in the international grain market will vary with its perceptions of the international environment.

\section{REFERENCES}

$\mathrm{Hu}, \mathrm{C}$, 1996. 'The impact of openness on China's industrial development', Beijing (mimeo).

Sheng, L., 1996. 'The market structure of China's manufacturing sector and implications for trade policy', Economic Research, 8:62-70.

World Bank, 1997. China 2020, World Bank, Washington, DC.

Zhang, S., Zhang, Y. and Wan, Z., 1997. 'Measuring the cost of China's trade protection', Economic Research, 2:12-22. 